\title{
An Empirical Study of HR Practices and Employee's Engagement in Banking Sector
}

\author{
Hatem Ali Helal ATEF (Corresponding Author) \\ Post Graduate Center \\ Limkokwing University of Creative Technology, Malaysia. \\ Dr. Valliappan Raju (Co-author) \\ Post Graduate Center \\ Limkokwing University of Creative Technology, Malaysia. \\ Rao Tahir Anees (Co-author) \\ Post Graduate Center \\ Limkokwing University of Creative Technology, Malaysia.
}

\author{
Luigi Pio Leonardo Cavaliere (Co-author) \\ Dipartimento di Economia \\ Università di Foggia, Foggia, Italy
Nordiana Ahmad Nordin (Co-author)
Faculty of Economics and Business \\ University Malaysia, Sarawak, Malaysia
}

Received: Mar. 11, 2021 Accepted: Apr. 29, 2021 Online published: May 20, 2021

doi:10.5296/ijhrs.v11i2.18661 URL: https://doi.org/10.5296/ijhrs.v11i2.18661 


\section{Abstract}

Companies around the world are grappling about how to improve employee engagement in an organization. For businesses to achieve long-term sustainability and well-being, employees must be engaged. Employees accept the job that could help them go through the ladder of their needs starting from the basic needs like security up to self-enhancement, for instance, self-ego or self-worth. Social exchange theory has been selected for this study, because this theory provide knowledge and understanding which is related to the study of employee engagement. This study used quantitative approach. The samples of this research were 132 employees of private banks in Sana'a, Yemen. Data retrieval used a questionnaire and the responses are accumulated through the structured questionnaires.

Keywords: employee engagement, reward \& recognition, job security

\section{Introduction}

In recent years, employee engagement has become a hot research subject amongst companies, human resource researchers, and management practitioners. Work engagement, as a constructive element of psychology, is becoming more common in occupational health psychology as a result of the rise of positive psychology. Employee engagement mentions to an employee's level of loyalty and participation with their company and its values. An involved employee understands the market context and collaborates with co-workers to enhance job performance for the betterment of the company. It is the workers' optimistic attitude toward the company and its standards. Employee engagement is a highlighted emotional attachment in which employee feel toward their organization, reason which motivate them to put additional effort in provide quality output to the organizational customers (Nazar, Jahan, Amoozegar, Anjum, \& Raju, 2020; Nazar, Ramzani, \& , Temoor Anjum, 2018). Employee engagement is linked to employees' self-image and willingness to provide input on working environment and workplace relationships, especially those that involve employee-supervisor interaction(Anees, Raju, \& Anjum, 2020).

The significance of human resources was emphasized during the reform of Yemen's banking sector, which included improvements in ownership, operational, financial, and management structures that resulted in more effective and productive bank operations, their participation in modern capital flows, the development of new banking products, and the availability of quality services to customers. The explanation for this is that the success of the banking sector's transformation processes necessitated dramatic changes in the labor force, which necessitated proper management, with adequate employee management playing a key role.

From the last few years up to now, there are several different forms of reasons that are believed to have influenced towards the employee's engagement. However, there are notmanystudieshavebeendoneonemployee'sengagementinserviceindustrylike banking industry in the context of Yemen. Consequently, further studies on different variablesthataffectingemployee'sengagementinbankingindustryisrequiredfromtime to time so that all the data is updated. Banking industry is one of the most stressed-out service sectors and this is the main reasons that might cause employees to be lack of engagement to their 
organization. Therefore, it is essential to study on what factors that may affect and most linked with employee's engagement in banking industry. Every organization need effective employees because they are the pillars of organizations performance success. So many studies have been conducted in different areas of human resource management as drivers of employee's engagement. However, job security and reward and recognition issue has been abandoned by scholars in organizational behavior discipline.

Many other researches have been published on various characteristics of HRM behaviours as a predicate of employee performance, but the majority of organizational behaviour researchers have ignored the topic of job security. Employee disengagement in the job market is caused by a variety of factors, including job insecurity, poor performance, workload, and poor reward and recognition. Companies need extremely energetic, knowledgeable, committed, and active workers in their workplace, just as they have in the past (Burton, W.N., Chen, C.Y., Li, X. \& Schultz, A.B, 2017; Bakker \& Schaufeli, 2008) employees who are more engaged at work are more likely to contribute to the organization's growth and productivity (Al-Mehrzi \& Singh, 2016; Gruman \& Saks, 2011). Highly involved employees are more likely to be passionate about their job and profoundly committed to their company's objectives, according to Bal, Kooij, \& De Jong (2013), while disengaged employees are much more concerned with time rather than energy or commitment during their position results. Only two factors of employee engagement are examined in this analysis. To the extent of the author's knowledge, none of these factors have been studied together in the background of the Yemeni banking sector prior to this research.

\section{Literature Review}

Employees who participate in work are more energetic and productive, which has a positive impact on organizational performance indicators (Kahn, 1990). According to Sun (2019), employee engagement is a strong long-term emotional and motivational attitude. They are committed to work, are willing to commit to work at any time, and enjoy a fun, comfortable and motivating work experience. Furthermore, several previous studies have shown that employee engagement has a positive impact on organizational performance (Katou, 2017; Hansen, Byrne \& Kiersch, 2014; Agarwal, 2014; Menguc, Auh, Fisher \& Haddad, 2013; Li, Sanders \& Frenkel, 2012; Dalal, Baysinger, Brummel \& Le Breton, 2012; Chughtai \& Buckley, 2011; Saks, 2006), financial performance (Demerouti \& Cropanzano, 2010; Xanthopoulou, 2009), return on assets and profitability (Schneider, Macey, Barbera and Martin, 2009), employee performance (Bakker \& Bal, 2010) and customer satisfaction (Salanova et al., 2005). Therefore, in today's competitive market environment, companies must focus on growing employee engagement to achieve long-term results (Chawla and Rai, 2017; Schneider et al., 2009). HR practises would be able to gain a competitive advantage with discretionary behaviours that are not part of the job description but contribute to organisational effectiveness if carried out by employees (Dash \& Pradhan, 2014).

\subsection{Job Security}

The degree to which a company should provide a secure job opportunity to its employees is 
referred to as job security (Herzberg, 1968). More precisely, job security refers to the possibility that an employee would be able to keep his or her job in that company for a fixed period of time (Delery \& Doty, 1996). Employees with low job security have poor physical and mental health (Strazdins, D'Souza, Lim, Broom \& Rodgers, 2004; Chirumbolo \& Hellgren, 2003; Hellgren \& Sverke, 2003), as well as psychological instability and Burnout (Strazdins, D'Souza, Lim, Broom \& Rodgers, 2004; Dekker \& Schaufeli, 1995). Furthermore, Gabris \& Simo (1995) found that job security is a motivating characteristic for workers, high job security will lead to high performance and low job security will reduce job motivation of employees (Miller, 2001). To put it another way, as long as workers become concerned about losing their jobs, their conduct begins to deteriorate (Boya, 2008; Domenighetti et al., 2000). In earlier empirical studies (Wang, Zhao \& Chen, 2017; Ugwu, 2017; Senol, 2011; Poyraz \& Kama, 2008; Kraimer, 2005; Sverke, Hellgren \& Näswall, 2002) it has also been determined that employment Safety is one of the most important incentive tools to motivate workers to improve job performance by improving negative work behaviors. In addition, according to the research of Chirumbolo (2003), job security comes with great encouragement to employees, which has a positive impact on employee performance.

However, according to Sokhanvar, Kakemam, Chegini, \& Sarbakhsh (2018), job security is not a major motivator for improving employee attitudes toward their jobs. Furthermore, Selenko (2013) discovered that workers with a high degree of work insecurity expect to perform better in order to keep their jobs. Job security, on the other hand, has been proposed by Chen, Warden, and Chang (2005) as a means by which organisations express their dedication to their workers, and employees respond in the sense of a positive attitude in the workplace. The paradigm of Social Exchange Theory (SET) and the mutual recognition norm both reflect this (Gouldner, 1960). Job security, on the other hand, must be differentiated from quantitative measures of instability, such as the number of dismissals and layoffs (Ellonen \& Nätti, 2015). As a result, this research hypothesizes the following;

Hypothesis 1: Job security has a positive effect on employee engagement.

\subsection{Rewards \& Recognition}

Skilled employees give positive result to their organizations. Reward and recognitions were confirmed to be associated to employee engagement. Improvement of employee's engagement needs to be enhanced by robust reward system. According to Bustamam, Teng, \& Abdullah (2014), reward refers to what workers are doing with their employers or what they receive in the form of money in exchange for their labour. Rewards are described by Jehanzeb, Rasheed, \& Rasheed (2012) as financial, non-financial, and psychological benefits bestowed by an organisation. As a result, rewards are perks that a company gives to its workers in exchange for good work. Extrinsic and intrinsic incentives, according to Peterson \& Luthans (2006), can be divided into two groups. Extrinsic and intrinsic, according to Lawler (1968), are essentially tangible benefits offered to workers after tasks are completed. Extrinsic rewards are inextricably related to organisation. Wage raises, vacations overseas, club membership, chosen lunch hours, remarkable identities, and bonuses are examples of extrinsic rewards (Weatherly, 2002). Rewards and recognition are essential organisational 
incentives that inspire workers to achieve organisational goals. The literature suggests that customer engagement has a positive effect on customer loyalty and other customer behavior. Engaged customers tend to adopt any action that may support the firm (Ansari, Anjum, Farrukh, \& Heidler, 2021).

As per Karatepe (2013), fair reward will inspire workers to provide excellent customer service. Furthermore, workers often express their opinions about their employer through the reward and recognition systems that they earn from that organisation (Ahmad, Kamaruddin, Aziz, \& Bakhtiar; 2012), and a scarcity of reward may result in an uncomfortable working atmosphere that reduces work efforts due to job loss (Lytle, 1998). Suan and Nasurdin (2014), on the other hand, discovered that reward had no impact on engagement in their research. The explanation, according to the writers, may be that workers believe their pay does not reflect their performance. Breevaart, Bakker, Hetland, Demerouti, \& Espevik (2014), from the other side, observed that if an organisation utilizes reward as an encouragement mechanism for good employee results, reward can have a positive effect on employees' behaviour and increase their engagement at work. Choo, Mat, and Al-Omari (2013) agreed with this viewpoint and looked at rewards and recognition as a predictor of employee engagement.

Prior researchers (Presbitero, 2017; Alias, Noor, and Hassan, 2014; Babakus, Yavas, \& Karatepe, 2017; Maslach \& Leiter, 2008) support the notion that rewards are an essential aspect of work life that can inspire workers to increase their involvement. But at the other hand, prior research (Sarti, 2014; De Gieter, 2008; Saks, et al., 2006) found that rewards and recognition have a negligible impact on employee engagement. According to Sharma, Lawrence, and Lowe (2010), reward and recognition only had a small capacity to describe sufficient variation in employee activity engagement. Based on SET, Karatepe et al. (2013) discovered that when workers receive sufficient rewards and recognition from their company, they feel obligated to it, resulting in higher levels of employee engagement. Workers' mutual recognition conduct is reflected in the degree of employee engagement, according to Carrillo, Robinson, Al-Ghassani, \& Anumba (2004), who found that the extent of employee engagement is dependent on the rewards employees obtain from their organisation. Furthermore, workers who are rewarded and recognised for their sufficient socio-emotional capital feel obligated to repay their organisation and demonstrate a higher degree of engagement. Vijayakumar \& Subha (2013) definition rewards can be recognized as financial and non-financial also as psychological benefits given by organizations to their employees in return for their good performance.

Weatherly et. al., (2002) pointed out that there are two kinds of rewards: extrinsic and intrinsic. Porter and Lawler (1968) defined extrinsic rewards as the compensation employees received when they completed required tasks. Therefore, the organization associates it with external rewards. There are many outside rewards such as salary increases, vacations abroad, club membership, preferred lunchtime, incredible titles and bonuses (Weatherly et al., 2002). Malhotra, Budhwar \& Prowse (2007) mentioned that extrinsic rewards can improve the relationship between workers and their supervisors. According to Victor \& Hoole (2017) Intrinsic reward are those linked to tasks and employees' personal interest which the do for reward purpose, which are not linked with work but, to individual interest. Adoko (2015) 
gives many examples of intrinsic rewards, such as confidence, self-esteem, participation, fairness, recognition, job satisfaction, creativity, empowerment, social status, personal development, and effective feedback. All are connected to individual interest. Employees achieve these rewards when the excel in their work. Employees perceive reward and recognition as tools that assist them to improve their work. According to Jeffries (1997) encouraged employees give their best to their employer if they get recognitions. A Performance Engagement Group survey report indicated that employees prefer daily recognition to rewards and bonuses. Jeffries, et. al., (1997) said that recognition should be consistent for long period of time to enhance employee engagement and it is not a must to be expensive.

Hypotheses 2: Rewards and recognition has a positive effect on employee engagement.

\subsection{Employees Engagement}

Recently, employee engagement (EE) has become amongst the most substantial concepts in the management field (Crawford, 2014). Leaders and managers worldwide concern more with the employee engagement concept as it is considered a vital element affecting the effectiveness and competitiveness (A. Khairy, H., 2019). Organizations and their employees have their own goals; both rely on the other to meet them. If employees are not given the perfect work-life, their disengagement sense toward the workplace tends to be stimulated and fails to achieve the organizational goals.

Schaufeli (2002) defined work engagement as "a positive, fulfilling, work-related state of mind, and it could be characterized by vigor, dedication, and absorption". Work environment is indeed correlated with the initiation and optimum functioning of work engagement (Christian, 2011). Employees' generally low engagement can be influenced by external causes such as illness or a weak work-life balance. Employees, on the other hand, are more likely to participate in their duties if they are called upon to fulfil their tasks, so management must have faith in them (Engelbrecht, 2017). The topic of employee engagement has acknowledged a lot of consideration in the scholarly literature once again. Employee engagement was first described by Kahn et. al., (1990) as the degree to which an employee is actively engaged, cognitively responsive, and emotionally attached to their jobs. Employee engagement study has exploded in recent years, with a attention on employees' engagement in the setting of their organisations (Kanwal, Farooq, Raju, Anjum, \& Zreen, 2020).

Rothbard (2001) is a characteristic of employee engagement, probably Kahn et al. (1990) The two key elements of psychological existence at work and participation are the consideration and engagement of the employees. Hence, employee engagement is well-defined as the psychological existence of a specific job that requires consideration and concentration (Bakker and Schaufeli, et al., 2008; Saks et al., 2006). Furthermore, May (2004) described participation as a mixture of cognitive and emotional work and work activity interactions that influence how people behave when performing tasks. However, Schaufeli et al. (2002) described employee engagement as an optimistic, satisfied, and work-related state of mind, characterized by vitality (a high level of energy and mental resilience), commitment 
(enthusiasm), and focus (full concentration during work).

\section{Theoretical Framework}

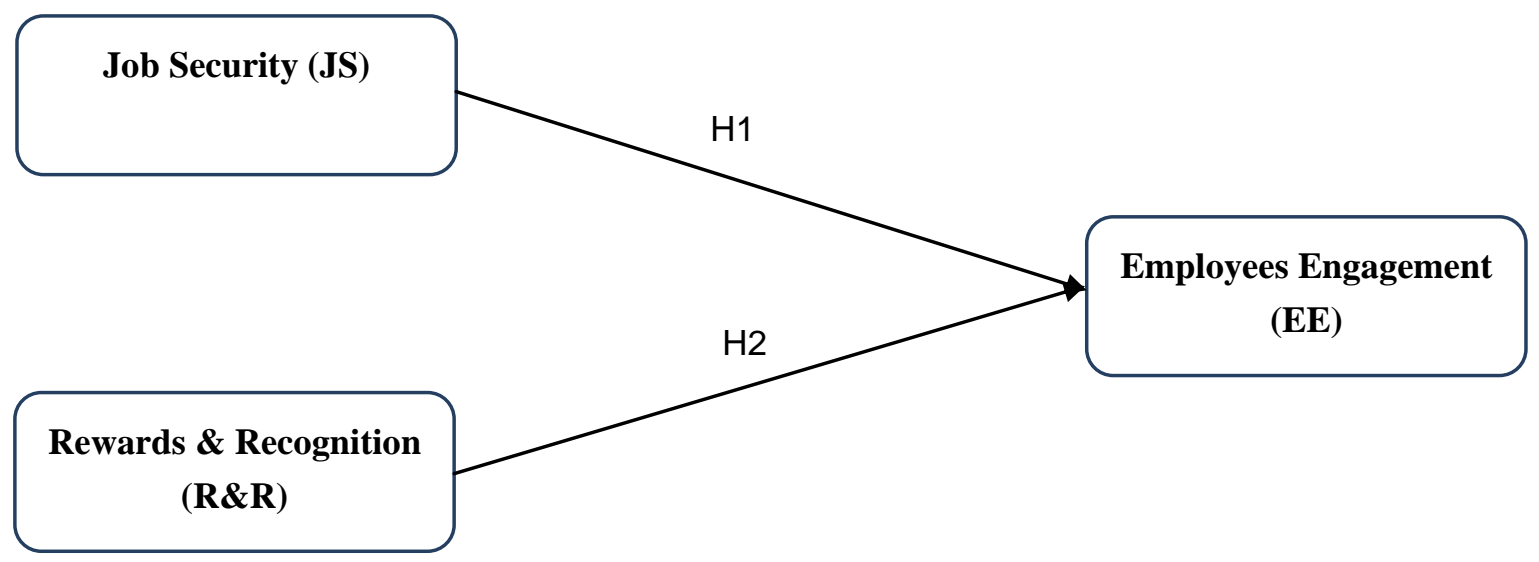

Figure 1. Theoretical Framework

\subsection{Methodology}

The creation of a literature review with a framework and hypothesis is the first and most important step in research methodology. Interviews, personal observation, surveys, and questionnaires are just some of the research design techniques available. However, the method used in this study is descriptive. Data was collected through questionnaire surveys and 132 questionnaires were distributed to private bank staff in Yemen to measure their participation. The relationship between IVs and DV in the Yemeni banking sector was measured using a stratified random sampling technique in this research because the sample is well-defined geographically and can be divided into clear, distinct groups called stratum. The questionnaires have been distributed in two different formats: soft copy and hard copy. The questionnaire used 5-point liker scale for most of the questions. To be more precise, the topic of job security and reward \& recognition can be classified as a descriptive topic used to ask questions and clarify the reasons behind the stated problem. This paper will follow the positivism as a philosophy that relies on observable facts and resources to produce dependable data. This approach considers that reality exists in itself, has its essence, and based on ontological hypotheses. The questionnaire is distributed by e-mail via the Internet in the form of electronic copy and the hard copy is distributed by personal mail and post. SEM-PLS route modelling was used to evaluate the proposed theoretical framework in this study (Anjum, Amoozegar, Nazar, \& Kanwal, 2020; Anjum, Farrukh, Heidler, \& Tautiva, 2021; Anjum, Sharifi, Nazar, \& Farrukh, 2018). The social exchange theory was chosen for this study because it has been used to address employee engagement by describing the factors that lead to employee engagement or disengagement. Sociologists Homans (1961) and Blau (1964) formulated this theory, which provides a presumed foundation for discussing why workers become more or less engaged in the company toward their jobs. According to the 
theory, obligations are established through a set of mutually beneficial relationships between parties. Employee engagement refers to the physical and psychological connection that exists between the employee and the employer, and it influences whether the employee performs well or poorly.

\section{Data Analysis}

PLS-SEM is a two-step procedure that includes measurements and structural models(Anjum, Ramzani, et al., 2018; Anees, Raju,Cavaliere, Heidler \& Nordin, 2020). LS-SEM is a two-step approach involving measurement and structural model evaluation in terms of this study. First, the internal consistency, convergent validity (CV), and discriminant validity (DV) of the measurement model should be assessed (Chin, 1998). Internal quality of consistency tests how well the objects test the latent construct (Hair Jr, Hult, Ringle, \& Sarstedt, 2017), Composite reliability (CR) scores were used to assess this. The results show that all constructs' CR scores surpassed the 0.7 threshold criterion, indicating that the scales used in this analysis have a high level of internal consistency.

Next, to evaluate the $\mathrm{CV}$ of the constructs, factor loadings and average variance extracted (AVE) were measured. $\mathrm{CV}$ is the degree to which a variable is positively associated with alternate measurements of the same construct. The loading factor should be 0.708 or greater, and 0.7 should be deemed similar enough to be appropriate (Anjum, Ramani Bai, \& Nazar, 2020a; Hair; Jr. et al., 2017; Anees, 2021). The threshold value of 0.5 was also met by the AVE scores of all constructs, suggesting an acceptable CV. The factor loadings, CR and AVE scores are presented in Table I (Hair et al., 2017).

DV is another criterion for testing the construct's validity. DV is the extent to which a construct by empirical standards is truly distinct from other constructs (Hair et al., 2017). DV is tested in this analysis with the aid of Fornell and Larcker's guidelines (1981), which notes that the AVE meaning square root should be greater than the square association with other constructs (Fornell \& Larcker, et. al., 1981). The following results in Table II show that DV was achieved.

Table I. Measurement Model (FL, CR \& AVE)

\begin{tabular}{|c|c|c|c|}
\hline Latent Variables & Factor Loading & CR & AVE \\
\hline Job Security & & 0.921 & 0.748 \\
\hline JS 1 & 0.715 & & \\
\hline JS 2 & 0.714 & & \\
\hline JS 3 & 0.714 & & \\
\hline JS 4 & 0.725 & & \\
\hline JS 5 & 0.801 & & \\
\hline RR 1 & & 0.869 & 0.721 \\
\hline RR 2 & 0.702 & & \\
\hline RR 3 & 0.741 & & \\
\hline Rewards \&ecognition & 0.705 & & \\
\hline EE 1 & & 0.909 & 0.669 \\
\hline EE 2 & 0.772 & & \\
\hline EE 3 & 0.754 & & \\
\hline
\end{tabular}




\begin{tabular}{|c|c|c|c|}
\hline EE 4 & 0.705 & & \\
\hline EE 5 & 0.721 & & \\
\hline EE 6 & 0.732 & & \\
\hline
\end{tabular}

Table II. Discriminant Validity

\begin{tabular}{|c|c|c|c|}
\hline Constructs & Job Security & $\begin{array}{c}\text { Rewards \& } \\
\text { Recognition }\end{array}$ & $\begin{array}{c}\text { Employees } \\
\text { Engagement }\end{array}$ \\
\hline Job Security & 0.864 & & \\
\hline Rewards \& Recognition & 0.541 & 0.849 & \\
\hline Employees Engagement & 0.485 & 0.501 & 0.817 \\
\hline
\end{tabular}

\subsection{Structural Model Assessment}

According to the recommendations of Hair et al. (2017), the Smart-PLS bootstrapping feature was used to test the value of the indirect impact analysis. A bootstrapping protocol of 5,000 interactions was used to generate t-values and standard errors in order to verify the statistical validity. Bootstrapping provides no claim as to the sampling distribution of data or the distribution form of variables; in comparison, it can also be used with certainty with a limited sample size. The bootstrapping methodology for indirect impact testing is therefore ideally suited for the PLS-SEM process (Anees, Nordin, Anjum, Cavaliere, \& Heidler, 2020; Anees, Raju, et al., 2020; Anjum, Ramani Bai, \& Nazar, 2020b; Anjum, V, \& Phung, 2020).

Table III. Direct Effect

\begin{tabular}{|c|lr|c|c|c|}
\hline Hypothesis & \multicolumn{1}{|c|}{ Path } & Path coefficient & t-statistics & p-values \\
\hline H1 & $\begin{array}{l}\text { Job Security } \\
\text { Employees }\end{array}$ & 0.251 & 2.125 & 0.001 \\
& Engagement & & & \\
\hline $\mathrm{H} 2$ & $\begin{array}{l}\text { Rewards } \\
\text { Recognition }\end{array}$ & $\rightarrow$ & 0.263 & 2.32 & 0.001 \\
& $\begin{array}{l}\text { Employees } \\
\text { Engagement }\end{array}$ & & & \\
\hline
\end{tabular}

\subsection{Coefficients of Determination $\left(R^{2}\right)$}

The decision coefficient ( $\mathbf{R}^{2}$ values) and direction coefficients (beta values) were criteria for evaluating how well the hypothesized relationships were supported by the evidence (Hair et al., 2017). $\mathbf{R}^{2}$ is rated as .25 (weak), .50 (moderate) and .75 (substantial). $\mathbf{R}^{2}$ was identified as a moderate value of .512. Therefore, the outcomes should be considered important to revenue success(Anjum, T., Ramzani, S.R., Nazar, N., Shahzad, I.A. and Salman, S., 2018; Hair Jr, Sarstedt, Ringle, \& Gudergan, 2017; Saeed Muhammad, Temoor Anjum, Fahad Khan Afridi, 2020). 
Table IV. $\mathrm{R}^{2}$

\begin{tabular}{|c|c|c|}
\hline Variable & $\mathbf{R}^{\mathbf{2}}$ & Range \\
\hline Employees Engagement & .512 & Moderate \\
\hline
\end{tabular}

\subsection{Discussion}

Hypothesis 1 predicted that job security positively influences employee's engagement. The outcomes of testing the structural equation model presented a positive outcome of job security on employee's engagement, as shown in Table III $(\beta=0.251, \mathrm{p}<0.001)$. The structural model shows that job security has a positive impact on employee engagement and support the previous studies results (Ahmed, S. \& Jaaffar, A. R. B; 2017). Accordingly, hypothesis 2 was acknowledged. Hypothesis 2 projected that Rewards \& Recognition positively influences Job employee's engagement. The outcomes of testing the structural equation model indicated a significant influence as illustrated in Table III $(\beta=0.263, p>$ 0.001). Organize employee recognition activities, such as monthly employee awards or a larger annual awards ceremony, to recognize employees who have performed well and done more in their daily work. When managers recognize and praise personal accomplishments, employees are more likely to take pride in their work and feel valued by the company.

\section{Conclusion}

Employee engagement is a practice that both managers and staff should be aware of. All workers should be valued for their future contributions. Employees should understand that their contributions are valued and that they are making a significant difference in the company. The results of this research shows that job security, as well as rewards and recognition, are important indicators of employee engagement. Yemen's banking sector should implement better policies about job security, rewards, and recognition to improve employee engagement. As a result, investing in workforce growth is very beneficial for a company that wants to maximise employee engagement.

\section{Limitations and Future Recommendation}

This study relies on individuals' self-reports for all variables in our model. To begin, this study focuses on and examines only a few studies that have been published in peer-reviewed journals and books. There are far too many studies, theories, antecedents, and results related to employee engagement. Second, in this research, employee engagement refers to individual engagement rather than team or organisational engagement. Since Kahn et. al., (1990) created the principle of engagement, a plethora of studies have been performed on employee engagement, but there is still much more research to be done. The third limitation, a comparative study, between the different variables in other sectors is recommended, the latter should incorporate additional factors and theories that influence employee's engagement. Another avenue of research is to identify and test other explanatory variables such as Job designing, career development opportunity and equal opportunity.

While the main organizational factor affecting employees engagement is human resource management practices, other factors such as leadership and work environment may be 
considered in the future. This is because there are many factors that can increase employee engagement, and these factors, in turn, affect the organization's bottom line. Finally, to avoid cross-industry influence, this research only focuses on one industry and does not consider the cultural impact of the connection between human resource management practices and employee engagement.

\section{References}

Ahmed, S., Haderi, S. M. S. A., Ahmad, F. B., Jaaffar, A. R. B., Walter, J., \& Al-Douis, G. A. A. (2017). Employee job security and performance relationship in developing economy through employee engagement: Critical analysis with PLS-SEM. International Journal of Economic Research, 14(19), 133-147.

A Khairy, H. (2019). How Organizational Merger affects Employees' Engagement and Job Security in the Hotel Industry? A Pre-Post Analysis. International Journal of Heritage, Tourism and Hospitality, 13(2), 245-262. https://doi.org/10.21608/ijhth.2019.92906

Adoko Obicci, P. (2015). Influence of extrinsic and intrinsic rewards on employee engagement (empirical study in public sector of Uganda). Management Studies and Economic Systems, 2(1), 59-70. https://doi.org/10.12816/0018083

Ahmad, N. A., Aziz, A. A., Kamaruddin, S. Y., Aziz, A. A., \& Bakhtiar, M. F. S. (2012). The Influence Of Direct Financial Compensation Towards Future-Graduates Career Choice In Hotel Industry. Journal of Tourism, Hospitality and Culinary Arts, 4(3), 25-26. https://doi.org/10.1201/b12752-22

Al Mehrzi, N., \& Singh, S. K. (2016). Competing through employee engagement: a proposed framework. International Journal of Productivity and Performance Management. https://doi.org/10.1108/IJPPM-02-2016-0037

Alaeddin, O., Thabet, A. A., Anees, R. T., \& Albashiti, B. (2021). The Effect of Enterprise Risk Management (Erm) on Organizational Performance: Empirical Investigation from The Diversified Industry of United Arab Emirates. Advances in Mathematics: Scientific Journal 10(3), 1735-1748. https://doi.org/10.37418/amsj.10.3.54

Alias, N. E., Noor, N., \& Hassan, R. (2014). Examining the mediating effect of employee engagement on the relationship between talent management practices and employee retention in the Information and Technology (IT) organizations in Malaysia. Journal of Human Resources Management and Labor Studies, 2(2), 227-242.

Anees, R. T., Heidler, P., Cavaliere, L. P. L., \& Nordin, N. A. (2021). Brain Drain in Higher Education. The Impact of Job Stress and Workload on Turnover Intention and the Mediating Role of Job Satisfaction at Universities. European Journal of Business and Management Research, 6(3), 1-8. https://doi.org/10.24018/ejbmr.2021.6.3.849

Anees, R. T., Nordin, N. A., Anjum, T., Cavaliere, L. P. L., \& Heidler, P. (2020). Evaluating the Impact of Customer Relationship Management ( CRM ) Strategies on Customer Retention ( A Study of Fast Food Chains in Pakistan ). Business Management and Strategy, 11(2), 
117-133. https://doi.org/10.5296/bms.v11i2.17934

Anees, R. T., Raju, D. V., \& Anjum, T. (2020). A Mediating Role of Adaptive Selling Behavior: Relationship between Emotional Intelligence and Sales Performance. Beverage Industry of Pakistan. International Journal of Psychosocial Rehabilitation, 24(1), $5266-5275$.

Anees, R. T., Raju, V., Cavaliere, L. P. L., Heidler, P., \& Nordin, N. A. (2020). The Effect of Emotional Intelligence and Market Orientation on Sales Performance: The Moderating Role of Entrepreneurial Orientation. PalArch's Journal of Archaeology of Egypt/Egyptology, 17(7), 6377-6397.

Anjum, T., Ramzani, S. R., Nazar, N., Shahzad, I. A., \& Salman, S. (2018). Entrepreneurial Intention: Does Entrepreneurial Education Matter in Pakistan? International Journal of Human Resource Studies, 8(3), 147-161. https://doi.org/10.5296/ijhrs.v8i3.13213

Anjum, T., Amoozegar, A., Nazar, N., \& Kanwal, N. (2020). Intervening effect of attitudes towards entrepreneurship: Correlation between passion and entrepreneurial intention. International Journal of Advanced Science and Technology, 29(5), 1327-1340.

Anjum, T., Farrukh, M., Heidler, P., \& Tautiva, J. A. D. (2021). Entrepreneurial Intention : Creativity, Entrepreneurship, and University Support. J. Open Innov. Technol. Mark. Complex, 7(1), 1-13. https://doi.org/10.3390/joitmc7010011

Anjum, T., Ramani Bai, V., \& Nazar, N. (2020a). Mediating role of attitudes to enhance the creativity disposition towards entrepreneurial intention. International Journal of Psychosocial Rehabilitation, 24(3), 542-553. https://doi.org/10.37200/IJPR/V24I3/PR200811

Anjum, T., Ramani Bai, V., \& Nazar, N. (2020b). Mediating role of attitudes to enhance the creativity disposition towards entrepreneurial intention. International Journal of Psychosocial Rehabilitation, 24(3), 542-553. https://doi.org/10.37200/IJPR/V24I3/PR200811

Anjum, T., Ramzani, S. R., Farrukh, M., Raju, V., Nazar, N., \& Shahzad, I. A. (2018). Entrepreneurial Intentions of Pakistani Students: The Role of Entrepreneurial Education, Creativity Disposition, Invention Passion \& Passion for Founding. Journal of Management Research, 10(3), 76. https://doi.org/10.5296/jmr.v10i3.13253

Anjum, T., Sharifi, S., Nazar, N., \& Farrukh, M. (2018). Determinants of Entrepreneurial Intention in Perspective of Theory of Planned Behaviour. Management Theory and Studies for Rural Business and Infrastructure Development, 40(4), 429-441. https://doi.org/10.15544/mts.2018.40

Anjum, T., V. R. B., \& Phung, S. P. (2020). Moderating Role of University Support on the relationship between Effective Entrepreneurship Education and Entrepreneurial Intention. Test Engineering Management, 83(March/April), 16377-16387.

Ansari, N. Y., Anjum, T., Farrukh, M., \& Heidler, P. (2021). Do Good, Have Good: A Mechanism of Fostering Customer Pro-Environmental Behaviors. Sustainability, 13, 3781. https:// doi.org/10.3390/su13073781 
Babakus, E., Yavas, U., \& Karatepe, O. M. (2017). Work engagement and turnover intentions. International Journal of Contemporary Hospitality Management. https://doi.org/10.1108/IJCHM-11-2015-0649

Bakker, A. B., Schaufeli, W. B., Leiter, M. P., \& Taris, T. W. (2008). Work engagement: An emerging concept in occupational health psychology. Work \& stress, 22(3), 187-200. https://doi.org/10.1080/02678370802393649

Bal, P. M., Kooij, D. T., \& De Jong, S. B. (2013). How do developmental and accommodative HRM enhance employee engagement and commitment? The role of psychological contract and SOC strategies. Journal of Management Studies, 50(4), 545-572. https://doi.org/10.1111/joms.12028

Blau, P. M. (1964). Social exchange theory. Retrieved September, 3(2007), p.62.

Boya, F. Ö., Demiral, Y., Ergör, A., AKVARDAR, Y., \& De Witte, H. (2008). Effects of perceived job insecurity on perceived anxiety and depression in nurses. Industrial Health, 46(6), 613-619. https://doi.org/10.2486/indhealth.46.613

Breevaart, K., Bakker, A., Hetland, J., Demerouti, E., Olsen, O. K., \& Espevik, R. (2014). Daily transactional and transformational leadership and daily employee engagement. Journal of occupational and organizational psychology, 87(1), 138-157. https://doi.org/10.1111/joop.12041

Burton, W. N., Chen, C. Y., Li, X., \& Schultz, A. B. (2017). The association of employee engagement at work with health risks and presenteeism. Journal of occupational and environmental medicine, 59(10), 988-992. https://doi.org/10.1097/JOM.0000000000001108

Bustamam, F. L., Teng, S. S., \& Abdullah, F. Z. (2014). Reward management and job satisfaction among frontline employees in hotel industry in Malaysia. Procedia-Social and Behavioral Sciences, 144, 392-402. https://doi.org/10.1016/j.sbspro.2014.07.308

Carrillo, P., Robinson, H., Al-Ghassani, A., \& Anumba, C. (2004). Knowledge management in UK construction: Strategies, resources and barriers. Project Management Journal, 35(1), 46-56. https://doi.org/10.1177/875697280403500105

Chawla, D., Dokadia, A., \& Rai, S. (2017). Multigenerational differences in career preferences, reward preferences and work engagement among Indian employees. Global Business Review, 18(1), 181-197. https://doi.org/10.1177/0972150916666964

Chen, J. F., Warden, C. A., \& CHANG, H. T. (2005). Motivators that do not motivate: The case of Chinese EFL learners and the influence of culture on motivation. TESOL quarterly, 39(4), 609-633. https://doi.org/10.2307/3588524

Chirumbolo, A., \& Hellgren, J. (2003). Individual and organizational consequences of job insecurity: A European study. Economic and Industrial Democracy, 24(2), 217-240. https://doi.org/10.1177/0143831X03024002004 


\section{Mll Macrothink}

International Journal of Human Resource Studies ISSN 2162-3058

Choo, L. S., Mat, N., \& Al-Omari, M. (2013). Organizational practices and employee engagement: A case of Malaysia electronics manufacturing firms. Business Strategy Series.

Christian, M. S., Garza, A. S., \& Slaughter, J. E. (2011). Work engagement: A quantitative review and test of its relations with task and contextual performance. Personnel psychology, 64(1), 89-136. https://doi.org/10.1111/j.1744-6570.2010.01203.x

Chughtai, A. A., \& Buckley, F. (2011). Work engagement: Antecedents, the mediating role of learning goal orientation and job performance. Career Development International. https://doi.org/10.1108/13620431111187290

Crawford, E. R., Rich, B. L., Buckman, B., \& Bergeron, J. (2013). The antecedents and drivers of employee engagement. In Employee engagement in theory and practice (pp. 71-95). Routledge. https://doi.org/10.4324/9780203076965-12

Chin, W. W. (1998). Modern Methods for Business Research. Modern Methods for Business Research. https://doi.org/10.4324/9781410604385

Dalal, R. S., Baysinger, M., Brummel, B. J., \& LeBreton, J. M. (2012). The relative importance of employee engagement, other job attitudes, and trait affect as predictors of job performance. Journal of Applied Social Psychology, 42, E295-E325. https://doi.org/10.1111/j.1559-1816.2012.01017.x

De Gieter, S., De Cooman, R., Pepermans, R., \& Jegers, M. (2008). Manage through rewards, not only through pay: Establishing the Psychological Reward Satisfaction Scale (PReSS). Reward management: Facts and trends in Europe, 97-117.

Dekker, S. W., \& Schaufeli, W. B. (1995). The effects of job insecurity on psychological health and withdrawal: A longitudinal study. Australian psychologist, 30(1), 57-63. https://doi.org/10.1080/00050069508259607

Delery, J. E., \& Doty, D. H. (1996). Modes of theorizing in strategic human resource management: Tests of universalistic, contingency, and configurational performance predictions. Academy of management Journal, 39(4), 802-835. https://doi.org/10.5465/256713

Demerouti, E., Cropanzano, R., Bakker, A., \& Leiter, M. (2010). From thought to action: Employee work engagement and job performance. Work engagement: A handbook of essential theory and research, 65, 147-163.

Domenighetti, G., d'Avanzo, B., \& Bisig, B. (2000). Health effects of job insecurity among employees in the Swiss general population. International Journal of Health Services, 30(3), 477-490. https://doi.org/10.2190/B1KM-VGN7-50GF-8XJ4

Ellonen, N., \& Nätti, J. (2015). Job insecurity and the unemployment rate: Micro-and macro-level predictors of perceived job insecurity among Finnish employees 1984-2008. Economic and Industrial Democracy, 561-71. https://doi.org/10.1177/0143831X13495720 


\section{I Macrothink}

International Journal of Human Resource Studies

ISSN 2162-3058 2021, Vol. 11, No. 2

Engelbrecht, A. S., Heine, G., \& Mahembe, B. (2017). Integrity, ethical leadership, trust and work engagement. Leadership \& Organization Development Journal. https://doi.org/10.1108/LODJ-11-2015-0237

Fornell, C., \& Larcker, D. F. (1981). Evaluating structural equation models with unobservable variables and measurement error. Journal of marketing research, 18(1), 39-50. https://doi.org/10.1177/002224378101800104

Gabris, G. T., \& Simo, G. (1995). Public sector motivation as an independent variable affecting career decisions. Public personnel management, 24(1), 33-51. https://doi.org/10.1177/009102609502400103

Gouldner, H. P. (1960). Dimensions of organizational commitment. Administrative Science Quarterly, 468-490. https://doi.org/10.2307/2390769

Gruman, J. A., \& Saks, A. M. (2011). Performance management and employee engagement. Human resource management review, 21(2), 123-136. https://doi.org/10.1016/j.hrmr.2010.09.004

Hansen, A., Byrne, Z., \& Kiersch, C. (2014). How interpersonal leadership relates to employee engagement. Journal of Managerial Psychology. https://doi.org/10.1108/JMP-11-2012-0343

Herzberg, F. I. (1968). One more time: How do you motivate employees? Harvard Business Review, 46(1), 53-62

Homans, G. C. (1961). Social behaviour: Its elementary forms. New York, NY: Harcourt, Brace \& World

Hair; Jr., M. S. M. R. S. P., Gudergan et al, Hair, J. F., Sarstedt, M., Ringle, C. M., \& Gudergan, S. P. (2017). Advanced Issues in Partial Least Squares Structural Equation Modeling. Los Angeles: SAGE Publications. https://doi.org/10.15358/9783800653614

Hair Jr, J. F., Hult, G. T. M., Ringle, C., \& Sarstedt, M. (2017). A primer on partial least squares structural equation modeling (PLS-SEM). Sage Publications.

Kanwal, N., Farooq, M., Raju, V., Anjum, T., \& Zreen, A. (2020). Intrapreneurial Behaviour of Employees in the Era of Transformative Marketing: A Multidisciplinary Approach. International Journal of Innovation, Creativity and Change, 13(6), 1337-1353.

Jeffries, R. (1997). Reaping the rewards of recognition. HR Focus, 74(1), 9-9.

Jehanzeb, K., Rasheed, M. F., \& Rasheed, A. (2012). Impact of rewards and motivation on job satisfaction in banking sector of Saudi Arabia. International Journal of Business and Social Science, 3(21).

Kahn, W. A. (1990). Psychological conditions of personal engagement and disengagement at work. Academy of Management Journal, 33, 692-724. https://doi.org/10.5465/256287 
Karatepe, O. M. (2013). High-performance work practices and hotel employee performance: The mediation of work engagement. International Journal of Hospitality Management, 32, 132-140. https://doi.org/10.1016/j.ijhm.2012.05.003

Katou, A. A. (2017). How does human resource management influence organisational performance? An integrative approach-based analysis. International Journal of Productivity and Performance Management. https://doi.org/10.1108/IJPPM-01-2016-0004

Kraimer, M. L., Wayne, S. J., Liden, R. C., \& Sparrowe, R. T. (2005). The role of job security in understanding the relationship between employees' perceptions of temporary workers and employees' performance. Journal of applied psychology, 90(2), 389. https://doi.org/10.1037/0021-9010.90.2.389

Lawler, E. E. (1968). Equity theory as a predictor of productivity and work quality. Psychological Bulletin, 70(6p1), 596. https://doi.org/10.1037/h0026848

Li, X., Sanders, K., \& Frenkel, S. (2012). How leader-member exchange, work engagement and HRM consistency explain Chinese luxury hotel employees' job performance. International Journal of Hospitality Management, 31(4), 1059-1066. https://doi.org/10.1016/j.ijhm.2012.01.002

Lytle, R. S., Hom, P. W., \& Mokwa, M. P. (1998). SERV* OR: A managerial measure of organizational service-orientation. Journal of retailing, 74(4), 455-489. https://doi.org/10.1016/S0022-4359(99)80104-3

Malhotra, N., Budhwar, P., \& Prowse, P. (2007). Linking rewards to commitment: an empirical investigation of four UK call centres. The International Journal of Human Resource Management, 18(12), 2095-2128. https://doi.org/10.1080/09585190701695267

Maslach, C., \& Leiter, M. P. (2008). Early predictors of job burnout and engagement. Journal of applied psychology, 93(3), 498. https://doi.org/10.1037/0021-9010.93.3.498

May, D. R., Gilson, R. L., \& Harter, L. M. (2004). The psychological conditions of meaningfulness, safety and availability and the engagement of the human spirit at work. Journal of occupational and organizational psychology, 77(1), 11-37. https://doi.org/10.1348/096317904322915892

Menguc, B., Auh, S., Fisher, M., \& Haddad, A. (2013). To be engaged or not to be engaged: The antecedents and consequences of service employee engagement. Journal of business research, 66(11), 2163-2170. https://doi.org/10.1016/j.jbusres.2012.01.007

Miller, B. (2001). The concept of security: Should it be Redefined?. The Journal of Strategic Studies, 24(2), 13-42. https://doi.org/10.1080/01402390108565553

Nazar, N., Jahan, S., Amoozegar, A., Anjum, T., \& Raju, V. (2020). The effects of total quality management practices on corporate social responsibility using supply chain model: A review of Malaysian hotel industry. Int. J. Supply Chain Manag, 9, 294-304. 


\section{Mll Macrothink}

International Journal of Human Resource Studies ISSN 2162-3058 2021, Vol. 11, No. 2

Nazar, N., Ramzani, S. R., Anjum, T., \& Shahzad, I. A. (2018). Impact of Entrepreneurial Orientation of Bank Performance in Pakistan. Business Management and Strategy, 9(1), 290-309. https://doi.org/10.5296/bms.v9i1.13212

Peterson, S. J., \& Luthans, F. (2006). The impact of financial and nonfinancial incentives on business-unit outcomes over time. Journal of applied Psychology, 91(1), 156. https://doi.org/10.1037/0021-9010.91.1.156

Porter, L. W., \& Lawler, E. E., (1968). Managerial attitudes and performance. Homewood, 111.: Irwin.

Poyraz, K., \& Kama, U. B. (2008). Perceived job security, job satisfaction, examining their impact on organizational commitment and intention to leave the job. Journal of Economics and Administrative Sciences, 13(2), 143-164.

Presbitero, A. (2017). How do changes in human resource management practices influence employee engagement? A longitudinal study in a hotel chain in the Philippines. Journal of Human Resources in Hospitality \& Tourism, 16(1), 56-70. https://doi.org/10.1080/15332845.2016.1202061

Rothbard, N. P. (2001). Enriching or depleting? The dynamics of engagement in work and family roles. Administrative science quarterly, 46(4), 655-684. https://doi.org/10.2307/3094827

Muhammad, S., Anjum, T., Afridi, F. K., \& Alasan, I. I. (2020). IMPACT OF TRANSFORMATIONAL LEADERSHIP ON PROJECT SUCCESS CRITERIA: THE MODERATING ROLE OF WORK ENGAGEMENT. PalArch's Journal of Archaeology of Egypt/Egyptology, 17(6), 7460-7476.

Saks, A. M. (2006). Antecedents and consequences of employee engagement. Journal of Managerial Psychology, 21(7), 600-619. https://doi.org/10.1108/02683940610690169

Salanova, M., Agut, S., \& Peiró, J. M. (2005). Linking organizational resources and work engagement to employee performance and customer loyalty: the mediation of service climate. Journal of applied Psychology, 90(6),1217. https://doi.org/10.1037/0021-9010.90.6.1217

Sarti, D. (2014). Job resources as antecedents of engagement at work: Evidence from a long-term care setting. Human Resource Development Quarterly, 25(2), 213-237. https://doi.org/10.1002/hrdq.21189

Schaufeli, W. B., Salanova, M., González-Romá, V., \& Bakker, A. B. (2002). The measurement of engagement and burnout: A two sample confirmatory factor analytic $\begin{array}{lllll}\text { approach. Journal of } & \text { Happiness }\end{array}$ https://doi.org/10.1023/A:1015630930326

Schneider, B., Macey, W. H., Barbera, K. M., \& Martin, N. (2009). Driving customer satisfaction and financial success through employee engagement. People \& Strategy, 32(2), 22-28. 
Selenko, E., \& Batinic, B. (2013). Job insecurity and the benefits of work. European Journal of Work and Organizational Psychology, 22(6), 725-736. https://doi.org/10.1080/1359432X.2012.703376

Senol, F. (2011). The effect of job security on the perception of external motivational tools: a study in hotel businesses. Journal of Economic and Social Studies, 1(2), 33. https://doi.org/10.14706/JECOSS11122

Sharma, U., Lawrence, S., \& Lowe, A. (2010). Institutional contradiction and management control innovation: A field study of total quality management practices in a privatized telecommunication company. Management Accounting Research, 21(4), 251-264. https://doi.org/10.1016/j.mar.2010.03.005

Sokhanvar, M., Kakemam, E., Chegini, Z., \& Sarbakhsh, P. (2018). Hospital nurses' job security and turnover intention and factors contributing to their turnover intention: A cross-Sectional study. Nursing and Midwifery Studies, 7(3), 133-140. https://doi.org/10.4103/nms.nms_2_17

Strazdins, L., D'Souza, R. M., Lim, L. L. Y., Broom, D. H., \& Rodgers, B. (2004). Job strain, job insecurity, and health: rethinking the relationship. Journal of occupational health psychology, 9(4), 296. https://doi.org/10.1037/1076-8998.9.4.296

Suan, C. L., \& Nasurdin, A. M. (2014). An empirical investigation into the influence of human resource management practices on work engagement: the case of customer-contact employees in Malaysia. International Journal of Culture, Tourism and Hospitality Research.

Sun, L., \& Bunchapattanasakda, C. (2019). Employee engagement: A literature review. International Journal of Human Resource Studies, 9(1), 63-80. https://doi.org/10.5296/ijhrs.v9i1.14167

Sverke, M., Hellgren, J., \& Näswall, K. (2002). No security: a meta-analysis and review of job insecurity and its consequences. Journal of occupational health psychology, 7(3), 242. https://doi.org/10.1037/1076-8998.7.3.242

Ugwu, C. C. (2017). Human resource management (HRM) practices and work engagement in Nigeria: The mediating role of psychological capital (PSYCAP). International Journal of Social Sciences and Humanities Review, 6(4).

Victor, J., \& Hoole, C. (2017). The influence of organisational rewards on workplace trust and work engagement. SA Journal of Human Resource Management, 15(1), 1-14. https://doi.org/10.4102/sajhrm.v15i0.853

Vijayakumar, V. T. R., \& Subha, B. (2013). Impact of rewards and recognition on employees job satisfaction and motivation in private banks of Tirunelveli City. International Research Journal of Business and Management, 62(3), 20-17.

Wang, H., Zhao, S., \& Chen, G. (2017). Firm-specific knowledge assets and employment arrangements: Evidence from CEO compensation design and CEO dismissal. Strategic Management Journal, 38(9), 1875-1894. https://doi.org/10.1002/smj.2604 
Weatherly, R. L. (2002). Effects of external rewards on internal motivation and job satisfaction (Doctoral dissertation, Texas Tech University).

Xanthopoulou, D., Bakker, A. B., Demerouti, E., \& Schaufeli, W. B. (2009). Reciprocal relationships between job resources, personal resources, and work engagement. Journal of Vocational behavior, 74(3), 235-244. https://doi.org/10.1016/j.jvb.2008.11.003

\section{Copyright Disclaimer}

Copyright for this article is retained by the author(s), with first publication rights granted to the journal.

This is an open-access article distributed under the terms and conditions of the Creative Commons Attribution license (http://creativecommons.org/licenses/by/4.0/). 